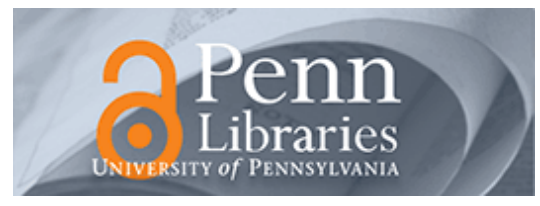

University of Pennsylvania

ScholarlyCommons

Business Economics and Public Policy Papers

Wharton Faculty Research

$12-2014$

\title{
'Feel the Warmth' Glow: A Field Experiment on Manipulating the Act of Giving
}

Amanda Chuan

Anya SavikhinSamek

Follow this and additional works at: https://repository.upenn.edu/bepp_papers

Part of the Business Commons, Economics Commons, and the Public Affairs, Public Policy and Public Administration Commons

\section{Recommended Citation}

Chuan, A., \& SavikhinSamek, A. (2014). 'Feel the Warmth' Glow: A Field Experiment on Manipulating the Act of Giving. Journal of Economic Behavior \& Organization, 108 198-211. http://dx.doi.org/10.1016/ j.jebo.2014.09.011

This paper is posted at ScholarlyCommons. https://repository.upenn.edu/bepp_papers/46

For more information, please contact repository@pobox.upenn.edu. 


\title{
'Feel the Warmth' Glow: A Field Experiment on Manipulating the Act of Giving
}

\author{
Abstract \\ We conducted a field experiment with a charitable group to investigate whether giving the donor an option \\ to write a personalized holiday card to the recipient influences giving behavior. Over 1500 households \\ were approached in a door-to-door campaign and randomized to either a treatment group, in which \\ donors were presented with the option to write their own card for the recipient, or a control group, in \\ which donors were not given the option to write their own card for the recipient. We predict that treatment \\ should increase contributions through making the gift more meaningful, but may also decrease \\ contributions by increasing the transaction and social costs of donating. We find evidence in favor of the \\ negative effects of costs from treatment, and no evidence of increased giving. We also observe that our \\ treatment crowds out small donors (donors giving $\$ 5$ or less). \\ Keywords \\ field experiment, altruism, meaning, social pressure \\ Disciplines \\ Business | Economics | Public Affairs, Public Policy and Public Administration
}




\title{
"Feel the Warmth" Glow: A Field Experiment on Manipulating the Act of Giving
}

\author{
Amanda Chuan ${ }^{1}$ and Anya C. (Savikhin) Samak ${ }^{1 *}$ \\ ${ }^{1}$ University of Pennsylvania \\ 3000 Steinberg Hall-Dietrich Hall, Philadelphia, PA 19104 \\ ${ }^{2}$ University of Wisconsin-Madison \\ 1300 Linden Drive, Madison, WI 53706
}

October 22, 2013

\begin{abstract}
We conducted a field experiment with a charitable group to investigate whether giving the donor an option to write a personal message to the recipient influences giving behavior. Over 1,500 households were approached in a door-to-door campaign and randomized to either a control or a treatment in which donors could include a card for the recipient. We predict that treatment should increase contributions through making the gift more meaningful, but may also decrease contribution rate by increasing the social or other cost of donating. We find evidence in favor of the cost effect, and no evidence of increased giving.
\end{abstract}

JEL Classifications: C93, H41, D64

Keywords: field experiment, altruism, meaning, social pressure

* Corresponding author: Anya (Savikhin) Samak - asamak@,wisc.edu. Phone: 608-262-5498

We thank the John Templeton Foundation for generous funding of this research under the Science of Philanthropy Initiative. We thank Xiang (Charis) Li, Edith Dobrez, Liz Jung, and Tristin Ganter for valuable research assistance. Any remaining errors are ours. 


\section{Introduction}

Charitable giving has continued to increase in economic importance, with $\$ 298.42$ billion - over $2 \%$ of U.S. GDP - contributed to charity in 2011 alone. ${ }^{1}$ At the same time, approximately $15-35 \%$ of total contributions are spent by charities on fundraising and administration, in mailings, door-to-door campaigns, phone-a-thons, and the like. ${ }^{2}$ While billions are spent on fundraising activities annually, more research is needed to determine the underlying motivation behind giving to charitable causes, and what kinds of fundraising approaches would be most fruitful for charities to pursue.

The related literature has used laboratory and field experiments to explore the underlying motivation to give and to investigate ways that fundraisers can increase giving (Vesterlund, 2006; Andreoni et al., 2007). The past 25 years have seen the emergence of two major theories that are considered key motivators in the decision to give: pure altruism, and warm glow. While purely altruistic individuals receive utility solely from increasing the welfare of others, individuals motivated by 'warm glow' receive utility from the act of giving itself (Andreoni, 1989; 1990; Korenok et al., 2013). Recent work has also identified the importance of social pressure or shame in the motivation to give (Andreoni et al., 2012; DellaVigna et al., 2012; Samak and Sheremeta, 2013).

We contribute to this area of research through a natural field experiment, which aims to increase the meaningfulness of giving. Such a manipulation is designed to increase the utility derived from the act of giving, which should then increase average amount donated. We identified one approach that charities use in practice, allowing the donor to write a letter to the recipient of their donation, which we believe makes the act of giving more meaningful for the donor. This approach lends itself well to 'adopt a child' type charities. For example, charities such as WorldVision or Compassion allow the donor to sponsor a child in a developing country and also to write letters to him/her. Both pure altruism (i.e., child benefits from a letter of encouragement) and warm glow (i.e., donor benefits from an increased sense of meaning

\footnotetext{
${ }^{1}$ As reported by Giving USA in its $57^{\text {th }}$ annual report, and re-printed in the popular press - see, for example, The Non-Profit Times, "2011 Giving Estimated at 298.42B - 06-19-2012" http://www.thenonprofittimes.com/article/detail/2011-giving-estimated-at-298-42b-4693 and Reuters, "U.S. Charitable Giving Approaches $\$ 300$ Billion in 2011," June 19, 2012, http://www.reuters.com/article/2012/06/19/ususa-charity-idUSBRE85I05T20120619

${ }^{2}$ As reported by the Center on Nonprofits and Philanthropy, Urban Institute, Center on Philanthropy, Indiana University. Nonprofit Overhead Cost Project: Facts and Perspectives.
} 
associated with the act of giving) are at play in this example. In an attempt to isolate the effect of the letter on the utility from the act of giving, we use anonymous letters and substitute a letter written by a volunteer in the control group.

We conducted our field experiment in partnership with a local charitable group, "Feel the Warmth," during their annual holiday door-to-door campaign. Over 1,500 households were approached and randomized to either a control condition or a treatment condition. The only difference between the two solicitations was that in the treatment condition, conditional upon donating any amount above $\$ 0$, donors could opt to include a holiday card with a message to the unknown recipient. In the control condition, on the other hand, donors were told that "Feel the Warmth" volunteers would provide holiday cards for recipients. The cards were not linked to the size of gift, and were not identified with the full name of the donor. By giving donors the opportunity to write a personalized message on a holiday card, the manipulation aimed to increase the donors' utility from giving. However, the manipulation may also increase the cost of giving, as discussed below.

We do not find evidence of an increase in donation amount as a result of treatment in our sample. To our surprise, the strongest result is that giving rates decrease. We propose that the decrease in giving in treatment may be due to the cost of giving. First, the social cost may be increased, in the sense that small donations may no longer be perceived as 'socially appropriate'. Second, there may be an opportunity cost of time from writing a card in the treatment group, or a cognitive cost from having to make multiple decisions (both the decision to give, and decision of whether to write the card) during the 'ask.'

Our contribution is to add to the literature on what types of solicitations may increase giving. Our findings also have practical relevance: fundraisers should be careful to consider the potential effects of solicitation approaches not only on altruistically motivated solicitees but also on those individuals who tend to be motivated by social pressure alone.

\section{Related Literature}

\subsection{Altruistic Giving}

One prediction of our model is that the experimental treatment would increase donations through enhancing the marginal utility of giving for those who already derive utility from altruistic acts. By providing donors the option of writing a personalized holiday card for a needy 
recipient, the treatment aims to increase the meaning donors associate with the act of giving. Making the charitable act more meaningful may increase contributions among solicitees motivated by pure or impure altruism.

Laboratory experiments have found evidence that individuals are more likely to engage in actions when they perceive those actions to be meaningful. For example, Liu and Aaker (2008) were able to increase the perceived meaningfulness of charitable acts (and, subsequently, donations to a charity) through priming laboratory subjects to think about the amount of time they might donate to the charity prior to the donation decision. Meaning also plays a role in increasing effort and worker satisfaction in the workplace (Ariely et al., 2008; Norton et al., 2011). For example, Norton et al. (2011) find that workers value products of their own making just as highly as (better quality) products made by professionals. Ariely et al. (2008) use evidence from lab experiments to demonstrate that worker effort increases when the work is more meaningful. In addition, individuals may find an action more personally meaningful if they perceive themselves to have had a greater role in bringing the act into fruition. Evidence from the psychology literature suggests that a greater sense of self-efficacy will increase giving through increasing anticipated feelings of guilt at the thought of not giving (Basil et al., 2008).

Researchers have also experimentally investigated the important roles of reciprocity (through experimental manipulations of donor gifts, see Falk, 2007; Gneezy and List, 2006), quality signaling (through manipulation of the existence of seed grants, leadership gifts, etc., see List and Lucking-Reiley, 2002; List and Rondeau, 2003; Kumru and Vesterlund, 2010; Bracha et al., 2011) and empathy (Verhaert and Van den Poel, 2011; Dickert et al., 2011; Basil et al., 2008). Decreasing the social distance between giver and recipient, i.e., through revealing the recipient's identity, has been shown to increase giving (Jenni and Loewenstein, 1997; Charness and Gneezy, 2008; Burnham, 2003; Bohnet and Frey, 1999a, b). Social identity and the sense of belonging to a group also plays a role in the decision to give to others (Candelo-Londono et al., 2011; Charness et al., 2011).

\subsection{Giving due to Social Pressure}

Another potential effect of treatment is to increase the social cost of giving through increasing the perception of the donation size needed to avoid the negative effects of social pressure. A recent literature reports that social pressure plays a major role in the decision to give. 
Laboratory experiments in which dictators are given the costly opportunity to opt out of participating tend to achieve lower participation rates and giving amounts than experiments where participation is mandatory (Lazear et al., 2012; Dana et al., 2006). Showing photos of subjects who gave the lowest amount has a big effect on increasing donations in a laboratory public goods game (Samak and Sheremeta, 2013). In the field, DellaVigna et al. (2012) cite social pressure motivations for giving as the reason that small donors opt out of being asked to give in a door-to-door campaign. Andreoni et al. (2012) present field evidence that individuals take extreme measures to avoid the social pressure associated with giving. In both of the above studies, donors are given the opportunity to opt out prior to being asked to give. This is different from our study, since we always ask donors to give, but the perceived cost of complying with the ask may be higher in the treatment that increases the meaning associated with giving.

\section{Conjectures}

Our aim is to present several competing theories that drive giving in treatment relative to control and provide conjectures for each. First, for donors who donate due to impure altruism (i.e., at least partly due to warm glow), the card treatment should enhance their utility from making a gift. In particular,

we predict that altruistic donors would increase the amount given, which would result in an increase on the intensive, rather than extensive, margin. This brings us to our first conjecture:

Conjecture 1: Treatment will increase giving by altruistically motivated donors, increasing donations on the intensive margin.

On the other hand, donors who are motivated solely by social pressure give only when asked. In DellaVigna et al. (2012), solicitees could decrease social pressure by giving any amount greater than $\$ 0$. However, we propose that the solicitation frame may change the cost of giving at certain contribution levels. For example, it may be that presenting donors with the

option of writing a personalized holiday message may signal to donors that a large donation is expected, even though donors were explicitly told that any amount was appreciated. Broadly, we call this the social cost effect. Suppose there exists a level above which gifts make an impact and below which giving a gift is functionally equivalent to giving nothing. Writing a holiday message is an act of altruism that is at odds with giving amounts below certain levels. Solicitees feel guiltier about small gifts when presented with the option of making their gift more 
meaningful, and so would rather give nothing (which solicitees know to be a frequent occurrence in fundraising campaigns).

In addition to a social cost, the card manipulation may increase the transaction cost from giving along two dimensions. First, introducing more choices (in this case, choosing to write a card or not) increases cognitive load. In their paper, Iyengar and Lepper (2000) find that individuals are more likely to undertake activities that have low, versus high, number of choices. Similarly, Bertrand et al. (2010) find that providing more options reduces take-up of loan offers. Similarly, we may expect potential donors to decline giving if the act of giving involves additional choices. Second, introducing the card may increase the time cost from giving - so that potential donors with a high opportunity cost may choose not to give. This brings us to our second conjecture:

Conjecture 2: Treatment will increase the perceived cost of giving, decreasing donations on the extensive margin.

Some donors in the treatment group chose not to write a message, and did not incur an opportunity cost of time. However, the heightened expectation of generosity and the cognitive cost of making that decision were nevertheless present for these donors.

\section{Experimental Design}

\subsection{Charities}

The two groups we collaborated with in this experiment are Feel the Warmth and Respond Now. Feel the Warmth, in Flossmoor, Illinois, is a student-run club at HomewoodFlossmoor High School that raises money every fall for the purpose of purchasing material to make blankets for families in need. These blankets typically go to Respond Now, a registered 501(c)(03) in neighboring Chicago Heights, IL, which solicits donations of food, clothing and furniture for its low-income clients. Respond Now agreed to deliver the blankets with the holiday cards that were collected as part of the experiment. Flossmoor, IL is a relatively wealthy suburb of Chicago, while nearby Chicago Heights, IL is one of the poorest. ${ }^{3}$

\footnotetext{
${ }^{3}$ In the 2007-2011 American Community Survey, per capita income in Flossmoor is reported to be $\$ 55,187$ with $2.4 \%$ below poverty level while per capital income in Chicago Heights is reported to be $\$ 17,539$ with $26 \%$ below poverty level (in 2011 inflation adjusted dollars).
} 
We worked with Feel the Warmth and the Advanced Placement Economics teacher at the high school to recruit 50 volunteers (ages 17-18) who would be trained to carry out the door-todoor campaign. The volunteers were either unpaid or received National Honors Society credit for their participation. While our students are a few years younger than those typically employed for this sort of experiment, note that students in the United States are not new to door-to-door solicitation. In fact, many students in Homewood-Flossmoor have engaged in door-to-door campaigns, raising money for extra-curricular activities and societies. However, this was the first time these students had been given a specific route and script to follow.

\subsection{Treatments}

We used a door-to-door campaign because this is the usual way that Feel the Warmth would raise funds, and because our design is easy to implement in this setting. We conducted a control and a treatment condition. The control and treatment conditions were identical in all respects except for the ability for donors to write their own message on a holiday card in the treatment group (see Appendix I for scripts). Solicitors were instructed to knock on the door, deliver the solicitation message about Feel the Warmth and the cost of one blanket (\$20), and ask for a donation. In the treatment condition, solicitors also offered the option of writing a message on the holiday card that would accompany the blanket. While all solicitees were informed of the holiday card opportunity, only those who donated could write a holiday message, since the holiday card would accompany the blanket they helped fund. To avoid reputation effects, donors were asked not to include their last name on the card, and could either include a first name or no name at all. Solicitees were told that if they donated but did not write a holiday message, a prewritten card would accompany the gift sent to the recipient. In the control condition, solicitors informed all solicitees that a pre-written holiday card would be included with the gift.

We conducted two two-hour sessions - a morning session and an afternoon session, both held on Saturday, December 1, 2012. We randomly assigned half of the solicitors to control or treatment for the morning session and trained them separately (so that neither group knew what the other would be doing). After solicitors returned for the afternoon, we flipped the groups such that the solicitors who implemented the control condition in the morning implemented the treatment condition in the afternoon, and the solicitors who implemented the treatment session in the morning implemented the control condition in the afternoon. While the control and treatment 
results from the morning session are the 'cleanest' in the sense that solicitors could not have mistakenly delivered the wrong message, the afternoon session allows us to control for solicitor fixed effects in the analysis.

\subsection{Procedures}

Solicitors arrived at $10 \mathrm{am}$ in the morning and were asked to pair up into groups of two. One person in each group recorded data while the other solicited donations for the entire day. We randomly assigned half of the pairs to control and half to treatment, and trained the two groups separately in a one-hour training session led by staff.

Following training, solicitors were given pre-selected routes to follow in the Homewood/Flossmoor area. Upon visiting each household, solicitors were required to record key information about each visit, including whether or not the door was opened, whether the individual donated, the amount of donation and (in the treatment condition) whether the donor chose to write a personalized message on a holiday card (see Appendix II). Solicitors were asked to return after they had solicited for two hours. After lunch, we completed a 15-minute training session on the solicitation requirements for the afternoon (during which all solicitors worked on the alternate treatment to the one from the morning). Solicitors were again given pre-selected routes to follow for the next 2 hours. ${ }^{4}$

\section{Results}

A total of 1,536 houses were approached during the experiment. Table 1 provides the summary statistics by treatment group and session. Over one third of households approached opened the door, and a little under half of those who opened the door gave a positive amount. Conditional on giving, the average amount given ranged between $\$ 11$ and $\$ 15$. Relative to similar door-to-door fundraising experiments (Landry et al., 2006, DellaVigna et al., 2012), about the same fraction of households opened the door, but a substantially higher fraction of

\footnotetext{
${ }^{4}$ The afternoon training session was shorter since solicitors were instructed to follow the previous procedure, only using a slightly different script. Groups that switched from control to treatment also received blank holiday cards to supply to interested donors, while unused holiday cards were taken away from groups that switched from treatment to control.
} 
households contributed. We suspect that the age of our solicitors may have contributed to the relatively high giving rates. ${ }^{5}$

First, we consider the role of treatment on probability of giving, which we expect may decrease for the treatment group based on the role of treatment at increasing costs (Conjecture 2). We find strong support for the role of costs in treatment - overall, the percentage of households contributing (conditional on opening the door) is $52 \%$ in the control group and only $43 \%$ in the treatment group, a statistically significant difference (Wilcoxon Mann-Whitney $p$-value $<0.05$ ). Individuals are $20 \%$ less likely to give when given the option to write a holiday card. Splitting the sample into morning and afternoon sessions, we find the same effect directionally for the morning and afternoon, but only the afternoon is significantly different. This brings us to the first result.

Result 1: The rate of giving is significantly higher in the control group relative to the treatment group, providing support for the hypothesis that treatment increased the costs of giving among some donors.

Result 1 is in line with our prediction that treatment may increase the cost of giving. In particular, we may expect relatively 'small' donations to be crowded out, similar to the social cost story in DellaVigna et al. (2012). We split the sample by the median gift amount (\$10) and consider those individuals giving less than $\$ 10$ 'small donors' and those giving \$10 or more 'large donors."

\footnotetext{
${ }^{5} \mathrm{We}$ also observe a higher rate of door opening and giving in the afternoon relative to the morning. It is possible that solicitor learning about how to knock/solicit may account for this difference, or it is possible that more people are home in the afternoon than in the morning. This difference does not hurt our results since we conducted both treatment and control at both times of day.
} 
Table 1: Summary Statistics with Non-parametric $t$-test results

\begin{tabular}{|c|c|c|c|}
\hline Session & & Control & Treatment \\
\hline \multirow[t]{10}{*}{ Morning } & Total households approached & 372 & 334 \\
\hline & Total households that answered door & 136 & 127 \\
\hline & $\%$ households that answered door & $36.6 \%$ & $38.0 \%$ \\
\hline & \# households that contributed & 58 & 47 \\
\hline & $\%$ households that contributed & $42.65 \%$ & $37.01 \%$ \\
\hline & Average donation per household that answered door & $\begin{array}{c}\$ 5.13 \\
(10.84)\end{array}$ & $\begin{array}{c}\$ 5.62 \\
(10.63)\end{array}$ \\
\hline & Average donation per household that gave & $\begin{array}{l}\$ 12.03 \\
(13.93)\end{array}$ & $\begin{array}{l}\$ 15.18^{* *} \\
(12.69)\end{array}$ \\
\hline & Median donation per household that gave & $\$ 10$ & $\$ 10$ \\
\hline & Total amount raised & $\$ 697.65$ & $\$ 713.31$ \\
\hline & $\%$ households that wrote card & N/A & $29.79 \%$ \\
\hline \multirow[t]{9}{*}{ Afternoon } & Total households approached & 393 & 437 \\
\hline & Total households that answered door & 150 & 178 \\
\hline & $\%$ households that answered door & $38.17 \%$ & $40.7 \%$ \\
\hline & $\begin{array}{l}\text { \# households that contributed } \\
\% \text { households that contributed }\end{array}$ & $\begin{array}{c}92 \\
61.33 \%\end{array}$ & $\begin{array}{c}83 \\
46.63 \% * * *\end{array}$ \\
\hline & Average donation per household that answered door & $\begin{array}{l}\$ 7.20 \\
(9.55)\end{array}$ & $\begin{array}{l}\$ 5.24 \\
(7.92)\end{array}$ \\
\hline & Average donation per household that gave & $\begin{array}{l}\$ 12.41 \\
(9.61)\end{array}$ & $\begin{array}{l}\$ 11.37 \\
(8.16)\end{array}$ \\
\hline & Median donation per household that gave & $\$ 10$ & $\$ 10$ \\
\hline & Total amount raised & $\$ 1,080$ & $\$ 932.36$ \\
\hline & $\%$ households that wrote card & N/A & $32.53 \%$ \\
\hline \multirow[t]{10}{*}{ Full Sample } & Total households approached & 765 & 771 \\
\hline & Total households that answered door & 286 & 305 \\
\hline & $\%$ households that answered door & $37.39 \%$ & $39.56 \%$ \\
\hline & \# households that contributed & 150 & 130 \\
\hline & $\%$ households that contributed & $52.45 \%$ & $42.62 \% * *$ \\
\hline & Average donation per household that answered door & $\begin{array}{l}\$ 6.22 \\
(10.22)\end{array}$ & $\begin{array}{l}\$ 5.40 \\
(9.13)\end{array}$ \\
\hline & Average donation per household that gave & $\begin{array}{l}\$ 12.26 \\
(11.49)\end{array}$ & $\begin{array}{l}\$ 12.76 \\
(10.17)\end{array}$ \\
\hline & Median donation per household that gave & $\$ 10$ & $\$ 10$ \\
\hline & Total amount raised & $\$ 1,777.65$ & $\$ 1,645.67$ \\
\hline & $\%$ households that wrote card & N/A & $31.54 \%$ \\
\hline
\end{tabular}

Asterisks denote significant differences between treatment and control. $* * * \mathrm{p}<0.01, * * \mathrm{p}<0.05, * \mathrm{p}<0.1$

Figure 1 provides kernel densities of all 'small gifts' in treatment and control, and provides additional evidence that smallest donors (who would have given less than \$5) are crowded out by the treatment. Notice that except for a spike in giving at the possible focal point of $\$ 5$, gifts below $\$ 5$ are less likely in treatment than in control. In Table 2, we regress treatment 
on indicators for a gift of less than $\$ 4-\$ 9$ (specifications 5-15) and observe that giving rates in treatment are significantly lower for each of those groups. This brings us to our next result:

Result 2: The decrease in giving rates in treatment is primarily due to the exit of small donors, providing some support for the social cost prediction.

\section{Figure 1: Donation amounts among 'small donors' in control and treatment}

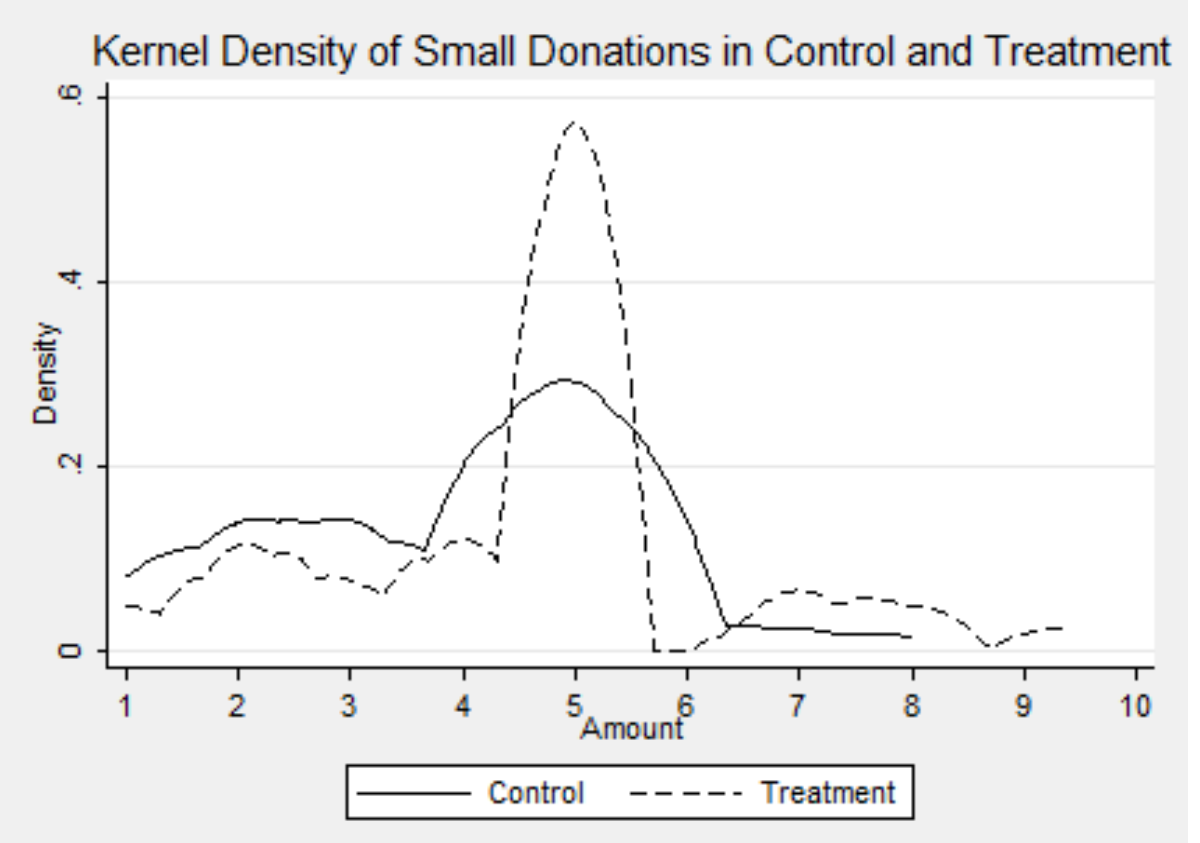

Next, we are interested in whether the meaning manipulation increased the gift amount, as would be predicted by Conjecture 1 . Over $30 \%$ of donors in treatment chose to write a card, suggesting that the card opportunity was valued at least by some. ${ }^{6}$ Overall, the average donation per household that gave is $\$ 12.26$ in the control group and \$12.76 in the treatment group, a difference that is in the direction we would expect if the card increased 'warm glow'. However, the difference is not large (only $4 \%$ higher) or statistically significant. When looking only at the

\footnotetext{
${ }^{6} 14$ out of 29 of those who gave less than $\$ 10$ in the treatment group chose to write a message on the holiday card we provided, and only 5 who gave below $\$ 5$ did so. 26 out of 53 of those who gave $\$ 10$ or more in the treatment group chose to write a message. When controlling for solicitor and solicitee demographics, the coefficient of card on the average amount given is positive $(\mathrm{p}=0.114)$. However, note that our paper is concerned with the self-sorting between giving and not giving that occurs given a solicitation attempt to increase the meaning inherent in the act of giving. Consequently our theory focuses primarily on the effect of presenting the option to write a message. Since the donor's decision to write a message is endogenous, we cannot make a causal inference about the influence of writing a message on giving behavior.
} 
morning session, we do find a significant difference in gift amount: $\$ 15.18$ in the treatment group, and only $\$ 12.03$ in the control group. Overall amount raised across the two treatments are also not significantly different: $\$ 1,777$ in the control group, and $\$ 1,645$ in the treatment group. ${ }^{7}$

Linear probability models in Table 3 provide further evidence that treatment lowers the probability of giving. Specifications 1 and 2 report on the probability of giving, conditional on opening the door, with and without solicitor and solicitee characteristics. We observe an overall decrease in giving rates in the treatment group, as well as a higher rate of giving in the afternoon session. In specifications 3-6, we investigate the rates of small (less than $\$ 10$ ) or large (\$10 or greater) giving. We find that in specification 3 , the decrease in giving rates due to treatment is concentrated among low donors only (coefficient -0.12 with $p$-value $<0.05$ ). While large donations are also decreased in treatment, the result is not statistically significant.

How can this result be reconciled with the literature finding that donations may increase when the act of giving is perceived to be more meaningful? First, it is possible that while our offer to write a holiday card was taken up by over $30 \%$ of donors, the card treatment did not make giving more meaningful to the point of affecting philanthropic behavior. Second, while Liu and Aaker (2008) made the donation decision more meaningful prior to making 'the ask', we attempt to make the donation decision more meaningful as part of the ask. Manipulating the meaning associated with giving may be more effective before the donation solicitation rather than during the donation solicitation. Second, the increased costs of giving in the treatment group may make it difficult for us to observe the effect described in Conjecture 1. Finally, manipulating emotional meaning may work better with 'warm list' rather than 'cold list' donors, since a larger proportion of 'warm list' donors may be altruistically motivated. Altruistically motivated donors may seek meaningful ways to give through volunteering and signing up with Compassion or WorldVision (the charities that allow donors to write letters to the recipient).

\footnotetext{
${ }^{7}$ This was enough to make over 170 blankets!
} 
Table 2: Giving Probabilities among Small(er) Donors

\begin{tabular}{|c|c|c|c|c|c|c|}
\hline VARIABLES & $\begin{array}{c}\text { (5) } \\
\text { Gave less } \\
\text { than } 4 \\
\end{array}$ & $\begin{array}{c}\text { (7) } \\
\text { Gave less } \\
\text { than } 5 \\
\end{array}$ & $\begin{array}{c}\text { (9) } \\
\text { Gave less } \\
\text { than } 6 \\
\end{array}$ & $\begin{array}{c}(11) \\
\text { Gave less } \\
\text { than } 7\end{array}$ & $\begin{array}{c}\text { (13) } \\
\text { Gave less } \\
\text { than } 8 \\
\end{array}$ & $\begin{array}{c}(15) \\
\text { Gave less } \\
\text { than } 9 \\
\end{array}$ \\
\hline Treatment & $\begin{array}{c}-0.0427 * * \\
(0.0170)\end{array}$ & $\begin{array}{c}-0.0448^{*} \\
(0.0237)\end{array}$ & $\begin{array}{c}-0.0573 * \\
(0.0293)\end{array}$ & $\begin{array}{c}-0.0611^{* *} \\
(0.0286)\end{array}$ & $\begin{array}{c}-0.0578^{*} \\
(0.0290)\end{array}$ & $\begin{array}{c}-0.0548^{*} \\
(0.0307)\end{array}$ \\
\hline $\begin{array}{l}\text { Afternoon } \\
\text { Session }\end{array}$ & $\begin{array}{l}0.0354 * \\
(0.0180)\end{array}$ & $\begin{array}{c}0.0522 * * \\
(0.0247)\end{array}$ & $\begin{array}{c}0.0613 * * \\
(0.0297)\end{array}$ & $\begin{array}{c}0.0638^{* *} \\
(0.0290)\end{array}$ & $\begin{array}{l}0.0590^{*} \\
(0.0297)\end{array}$ & $\begin{array}{l}0.0611^{*} \\
(0.0312)\end{array}$ \\
\hline Constant & $\begin{array}{c}0.0549 * * * \\
(0.0136)\end{array}$ & $\begin{array}{c}0.0635^{* * *} * \\
(0.0189)\end{array}$ & $\begin{array}{c}0.150^{* * *} \\
(0.0244)\end{array}$ & $\begin{array}{c}0.155^{* * *} * \\
(0.0241)\end{array}$ & $\begin{array}{c}0.161^{* * *} \\
(0.0250)\end{array}$ & $\begin{array}{c}0.164 * * * \\
(0.0251)\end{array}$ \\
\hline $\begin{array}{c}\text { Observations } \\
\text { R-squared }\end{array}$ & $\begin{array}{c}590 \\
0.014\end{array}$ & $\begin{array}{c}590 \\
0.017\end{array}$ & $\begin{array}{c}590 \\
0.013\end{array}$ & $\begin{array}{c}590 \\
0.014\end{array}$ & $\begin{array}{c}590 \\
0.012\end{array}$ & $\begin{array}{c}590 \\
0.011\end{array}$ \\
\hline
\end{tabular}

Robust standard errors in parentheses. Regressions are clustered by team. Team is missing for 1 observation among this sample; hence we have 590 observations here as opposed to 591 in the previous table.

*** $\mathrm{p}<0.01,{ }^{* *} \mathrm{p}<0.05,{ }^{*} \mathrm{p}<0.1$ 
Table 3: Regressions of Treatment Status on Giving

\begin{tabular}{|c|c|c|c|c|c|c|c|c|}
\hline \multirow[t]{3}{*}{ Dep. Var: } & \multicolumn{2}{|c|}{ Indicator for Giving } & \multicolumn{4}{|c|}{ Indicator for Giving } & \multicolumn{2}{|c|}{$\begin{array}{l}\text { Average Donation } \\
\quad \text { (including } 0 \text { ) }\end{array}$} \\
\hline & & & \multicolumn{2}{|c|}{ small gifts $(<10)$} & \multicolumn{2}{|c|}{ large gifts $(\geq 10)$} & & \\
\hline & (1) & (2) & (3) & (4) & $(5)$ & (6) & (7) & $(8)$ \\
\hline Treatment & $\begin{array}{l}-0.109^{*} \\
(0.0598)\end{array}$ & $\begin{array}{l}-0.100^{*} \\
(0.0499)\end{array}$ & $\begin{array}{l}-0.115 * * \\
(0.0503)\end{array}$ & $\begin{array}{l}-0.0706 \\
(0.0606)\end{array}$ & $\begin{array}{l}-0.0911 \\
(0.0641)\end{array}$ & $\begin{array}{l}-0.0706 \\
(0.0606)\end{array}$ & $\begin{array}{c}0.542 \\
(1.196)\end{array}$ & $\begin{array}{c}0.516 \\
(1.288)\end{array}$ \\
\hline & $0.143^{* *}$ & $0.144^{* *}$ & $0.142^{* * *}$ & $0.111^{*}$ & $0.122 *$ & $0.111^{*}$ & -1.539 & -1.011 \\
\hline Afternoon Session & $(0.0601)$ & $(0.0547)$ & $(0.0484)$ & $(0.0595)$ & $(0.0676)$ & $(0.0595)$ & & $(1.898)$ \\
\hline Female & & $\begin{array}{c}0.0371 \\
(0.0391)\end{array}$ & & $\begin{array}{c}0.0288 \\
(0.0444)\end{array}$ & & $\begin{array}{c}0.0288 \\
(0.0444)\end{array}$ & & $\begin{array}{l}-0.776 \\
(1.816)\end{array}$ \\
\hline Black & & $\begin{array}{l}-0.109^{*} \\
(0.0544)\end{array}$ & & $\begin{array}{c}-0.178 * * * \\
(0.0517)\end{array}$ & & $\begin{array}{c}-0.178 * * * \\
(0.0517)\end{array}$ & & $\begin{array}{l}-1.505 \\
(1.827)\end{array}$ \\
\hline Hispanic & & $\begin{array}{l}0.0841 \\
(0.118)\end{array}$ & & $\begin{array}{l}-0.0538 \\
(0.204)\end{array}$ & & $\begin{array}{l}-0.0538 \\
(0.204)\end{array}$ & & $\begin{array}{l}-3.364 \\
(4.199)\end{array}$ \\
\hline Other Race & & $\begin{array}{l}-0.108 \\
(0.117)\end{array}$ & & $\begin{array}{l}-0.0888 \\
(0.134)\end{array}$ & & $\begin{array}{l}-0.0888 \\
(0.134)\end{array}$ & & $\begin{array}{c}5.029 \\
(7.377)\end{array}$ \\
\hline Female Asker & & $\begin{array}{c}0.0133 \\
(0.0937)\end{array}$ & & $\begin{array}{c}0.0211 \\
(0.0978)\end{array}$ & & $\begin{array}{c}0.0211 \\
(0.0978)\end{array}$ & & $\begin{array}{l}-0.134 \\
(1.440)\end{array}$ \\
\hline Female Recorder & & $\begin{array}{l}0.0714 \\
(0.104)\end{array}$ & & $\begin{array}{l}0.0690 \\
(0.112)\end{array}$ & & $\begin{array}{l}0.0690 \\
(0.112)\end{array}$ & & $\begin{array}{c}1.414 \\
(1.252)\end{array}$ \\
\hline Constant & $\begin{array}{l}0.449 * * * \\
(0.0599)\end{array}$ & $\begin{array}{c}0.415^{* * *} \\
(0.0814)\end{array}$ & $\begin{array}{c}0.240^{* * *} \\
(0.0417)\end{array}$ & $\begin{array}{c}0.343 * * * \\
(0.0937)\end{array}$ & $\begin{array}{c}0.346 * * * \\
(0.0642)\end{array}$ & $\begin{array}{c}0.343 * * * \\
(0.0937)\end{array}$ & $\begin{array}{c}13.18 * * * \\
(1.555)\end{array}$ & $\begin{array}{c}12.87 * * * \\
(1.990)\end{array}$ \\
\hline Observations & 590 & 485 & 418 & 402 & 489 & 402 & 273 & 233 \\
\hline R-squared & 0.030 & 0.050 & 0.040 & 0.057 & 0.024 & 0.057 & 0.005 & 0.019 \\
\hline
\end{tabular}




\section{Conclusion}

We conducted a door-to-door field experiment to investigate whether we could increase the meaning associated with the act of giving by providing an opportunity to send a holiday message to the recipient. We do not observe an effect of increased giving as a result of this manipulation, but do observe a significant decrease in giving rates, concentrated among small donors. The decrease in giving rates can be explained by greater cost of giving in the treatment condition. This cost could be driven by increased perceived social cost from giving a small gift, opportunity cost of time, or cognitive cost from an additional choice set.

While we document the decrease in giving due to cost, several explanations can account for why increasing the meaning associated with giving did not lead to significant increases in donation amounts. In particular, we used a 'cold list', while our manipulation may be more effective with 'warm list' donors or a larger sample of altruistically motivated donors. In addition, this particular treatment, despite being taken up by over $30 \%$ of donors, may not enhance meaning. This could be due to being administered simultaneously with the ask, rather than being administered immediately before the ask.

Our findings are practically relevant for practitioners. In particular, fundraisers should be careful to consider the potential effects of solicitation approaches on the cost of giving - either from social cost, cognitive cost, or time cost. Avenues for future work include considering the effect of emotional meaning manipulations on warm list donors and the role of emotional meaning in the decision to give time (volunteer). It will also be interesting to consider the effects of different manipulations conducted just prior to, rather than during, an ask - these would be free from a cost of giving effect. 


\section{References}

Andreoni, J., 1989. Giving with Impure Altruism: Applications to Charity and Ricardian Equivalence. Journal of Political Economy 97 (6), 1447-1458.

Andreoni, J., 1990. Impure Altruism and Donations to Public Goods: A Theory of Warm-Glow Giving. The Economic Journal 100 (401), 464-477.

Andreoni, J., 2006. Philanthropy. In: Gerard-Varet L.-A., Kolm S.-C., Ythier J. M. (Eds.), Handbook on the Economics of Giving, Reciprocity and Altruism. Elsevier, pp. 1201-1269.

Andreoni, J., Harbaugh, W.T., Vesterlund, L. 2008. Altruism in Experiments. In: Durlauf, S., Blume, L.E. (Eds.), The New Palgrave Dictionary of Economics, $2^{\text {nd }}$ Edition. Palgrave Macmillan.

Andreoni, J., Petrie, R., 2004. Public goods experiments without confidentiality: a glimpse into fund-raising. Journal of Public Economics 88, 1605-1623.

Andreoni, J., Rao, J.M., 2011. The power of asking: How communication affects selfishness, empathy, and altruism. Journal of Public Economics 95, 513-520.

Andreoni, J., Rao, J.M., Trachtman, H., 2012. Avoiding the Ask: A Field Experiment on Altruism, Empathy, and Charitable Giving. NBER Working Paper No. 17648.

Ariely, D., Bracha, A., Meier, S., 2009. Doing Good or Doing Well? Image Motivation and Monetary Incentives in Behaving Prosocially. The American Economic Review 99 (1), 544-555.

Ariely, D., Kamenica, E., Prelec, D., 2008. Man's search for meaning: The case of Legos. Journal of Economic Behavior \& Organization 67, 671-677.

Basil, D.Z., Ridgway, N.M., Basil, M.D., 2008. Guilt and Giving: A Process Model of Empathy and Efficacy. Psychology \& Marketing 25 (1), 1-23.

Benabou, R., Tirole, J., 2006. Incentives and Prosocial Behavior. The American Economic Review 96 (5), 1652-1678.

Bertrand, M., Karlan, D., Mullainathan, S., Shafir, E and Zinman, J. 2010. What's Advertising Content Worth? Evidence from a Consumer Credit Marketing Field Experiment. Quarterly Journal of Economics, 125(1): 263-305.

Bohnet, I., Frey, B.S., 1999, a. The sound of silence in prisoner's dilemma and dictator games. Journal of Economic Behavior \& Organization 38, 43-57.

Bohnet, I., Frey, B.S., 1999, b. Social Distance and Other-Regarding Behavior in Dictator Games: Comment. The American Economic Review 89 (1), 335-339. 
Bracha A., Menietti, M., Vesterlund, L. (2011). Seeds to succeed? Sequential giving to public projects. Journal of Public Economics 95, 416-427.

Burnham, T.C., 2003. Engineering altruism: a theoretical and experimental investigation of anonymity and gift giving. Journal of Economic Behavior \& Organization 50, 133-144.

Candelo-Londoño, N., Croson, R.T.A., Li, X., 2011. Social Exclusion and Identity: A Field Experiment with Hispanic Immigrants.

Charness, G., Gneezy, U., 2008. What's in a name? Anonymity and social distance in dictator and ultimatum games. Journal of Economic Behavior \& Organization 68, 29-35.

Charness, G., Cobo-Reyes, R., Jimenez, N., 2011. Efficiency, team building, and identity in a public-goods game. Working Paper.

Dana, J., Cain, D.M., Dawes, R.M., 2006. What you don't know won't hurt me: Costly (but quiet) exit in dictator games. Organizational Behavior and Human Decision Processes 100, 193201.

DellaVigna, S., List, J.A., Malmendier, U., 2012. Testing for Altruism and Social Pressure in Charitable Giving. The Quarterly Journal of Economics 127 (1), 1-56.

Dickert, S., Sagara, N., Slovic, P., 2011. Affective Motivations to Help Others: A Two-stage Model of Donation Decisions. Journal of Behavioral Decision Making 24, 361-376.

Falk, A., 2007. Gift Exchange in the Field. Econometrica 75 (5), 1501-1511.

Gneezy, U., List, J.A., 2006. Putting Behavioral Economics to Work: Testing for Gift Exchange in Labor Markets Using Field Experiments. Econometrica 74 (5), 1365-1384.

Iyengar, Sheena S., and Lepper, Mark R. 2000. When Choice is Demotivating: Can One Desire Too Much of a Good Thing? Journal of Personality and Social Psychology, 79(6): 995-1006.

Jenni, K.E., Loewenstein, G., 1997. Explaining the "Identifiable Victim Effect." Journal of Risk and Uncertainty 14, 235-257.

Korenok, O., Millner, E.L., Razzolini, L., 2013. Impure altruism in dictators' giving. Journal of Public Economics 97, 1-8.

Kumru, C.S., Vesterlund, L., 2010. The Effect of Status on Charitable Giving. Journal of Public Economic Theory 12 (4), 709-735.

Landry, C.E., Lange, A., List, J.A., Price, M.K., Rupp, N.G., 2006. Toward an Understanding of the Economics of Charity: Evidence from a Field Experiment. The Quarterly Journal of Economics 121 (2), 747-782. 
Lazear, E., Malmendier, U., Weber, R., 2012. Sorting in Experiments with Application to Social Preferences. American Economic Journal: Applied Economics 4 (1), 136-163.

List, J.A., Lucking-Reiley, D., 2002. The Effects of Seed Money and Refunds on Charitable Giving: Experimental Evidence from a University Capital Campaign. Journal of Political Economy 110 (1), 215-233.

List, J.A., Rondeau, D., 2003. The impact of challenge gifts on charitable giving: an experimental investigation. Economics Letters 79, 153-159.

Liu, W., Aaker, J., 2008. The Happiness of Giving: The Time-Ask Effect. Journal of Consumer Research 35, 543-557.

Norton, M.I., Mochon, D., Ariely, D., 2012. The IKEA effect: When labor leads to love. Journal of Consumer Psychology 22, 453-460.

Samak, A.C., Sheremeta, R.M., 2013. Visibility of Contributors and cost of Information: An Experiment on Public Goods. Working Paper.

Verhaert, G.A., Van den Poel, D., 2011. Empathy as added value in predicting donation behavior. Journal of Business Research 64, 1288-1295.

Vesterlund, L., 2006. Why do People Give? In: Steinberg, R., Powell, W.W. (Eds.), The Nonprofit Sector, $2^{\text {nd }}$ edition, Yale, pp. 568-587. 


\section{Appendix I: Solicitation scripts}

\section{Control Group}

Hello, we are volunteers from the Feel the Warmth organization. A few years ago, a couple of high school students in the Homewood-Flossmoor area started a service project to help people in need keep warm during the cold holiday season. Each year high school students raise money to purchase fleece material, which are used to make blankets. Today we are asking you to make a difference in somebody's holiday season and donate. \$20 will purchase one fleece blanket, but we appreciate any amount you contribute. A holiday card for a person in need will accompany your gift.

\section{Treatment Group}

Hello, we are volunteers from the Feel the Warmth organization. A few years ago, a couple of high school students in the Homewood-Flossmoor area started a service project to help people in need keep warm during the cold holiday season. Each year high school students raise money to purchase fleece material, which are used to make blankets. Today we are asking you to make a difference in somebody's holiday season and donate. \$20 will purchase one fleece blanket, but we appreciate any amount you contribute. If you give a gift, you can write a personalized holiday card for the person who received the blanket you contributed to. 


\section{Appendix II: Data sheets}

Figure A1: Data Sheet for Asker

A

Route 1: Card

Feel the Warmth

\begin{tabular}{|c|c|c|c|c|}
\hline time & address & Did they give? & Amount Given & $\begin{array}{l}\text { Did they fill out } \\
\text { their own Card? }\end{array}$ \\
\hline & $100 \mathrm{ABC}$ Street & $\mathrm{Y} \square$ | N口 & & $\mathrm{Y} \square$ | N口 \\
\hline & 102 ABC Street & $\mathrm{Y} \square$ | N $\square$ & & Y $\square$ | N口 \\
\hline & 103 ABC Street & $\mathrm{Y} \square$ | N $\square$ & & $\mathrm{Y} \square$ | N口 \\
\hline & 104 ABC Street & $\mathrm{Y} \square$ | N $\square$ & & $\mathrm{Y} \square$ | N口 \\
\hline & 105 ABC Street & $\mathrm{Y} \square$ | N $\square$ & & $\mathrm{Y} \square$ | N口 \\
\hline & 106 ABC Street & Y $\square$ | N $\square$ & & Y $\square$ | N口 \\
\hline & 107 ABC Street & $\mathrm{Y} \square$ | N $\square$ & & $\mathrm{Y} \square$ | N口 \\
\hline & $108 \mathrm{ABC}$ Street & $\mathrm{Y} \square \mid \mathrm{N} \square$ & & Y \\
\hline & 109 ABC Street & $\mathrm{Y} \square \mid \mathrm{N} \square$ & & Y \\
\hline & 110 ABC Street & $\mathrm{Y} \square$ | N口 & & Y $\square$ | N口 \\
\hline & 111 ABC Street & $\mathrm{Y} \square \mid \mathrm{N} \square$ & & $\mathrm{Y} \square$ | N口 \\
\hline & 112 ABC Street & $\mathrm{Y} \square$ | N口 & & Y $\mathrm{|} \mathrm{N \square}$ \\
\hline & 113 ABC Street & $\mathrm{Y} \square \mid \mathrm{N} \square$ & & Y $\square$ | N口 \\
\hline & 114 ABC Street & $\mathrm{Y} \square$ | N $\square$ & & $\mathrm{Y} \square$ | N口 \\
\hline & 115 ABC Street & $\mathrm{Y} \square \mid \mathrm{N} \square$ & & $\mathrm{Y} \square$ | N口 \\
\hline & 116 ABC Street & $\mathrm{Y} \square \mid \mathrm{N} \square$ & & $\mathrm{Y} \square$ | N口 \\
\hline & 117 ABC Street & $\mathrm{Y} \square$ | N口 & & $\mathrm{Y} \square$ | N口 \\
\hline & 118 ABC Street & $\mathrm{Y} \square$ | N $\square$ & & $\mathrm{Y} \square$ | N口 \\
\hline & 119 ABC Street & $\mathrm{Y} \square$ | N口 & & $\mathrm{Y} \square$ | N口 \\
\hline
\end{tabular}

Note: Addresses have been falsified to protect subject identity. 
Figure A2: Data Sheet for Recorder

$\mathbf{R}$

Route 1: Card

Feel the Warmth

\begin{tabular}{|c|c|c|c|c|c|}
\hline address & $\begin{array}{l}\text { Did you } \\
\text { aproach } \\
\text { the house? }\end{array}$ & $\begin{array}{l}\text { Did they } \\
\text { open the } \\
\text { door? }\end{array}$ & Race & Gender & Notes \\
\hline 100 ABC Str eet & $\mathrm{Y} \square \mid \mathrm{N} \square$ & $\mathrm{Y} \square \mid \mathrm{N} \square$ & White $\square$ | Black $\square$ | Hispanic $\square$ | Other $\square$ & & \\
\hline 102 ABC Street & $\mathrm{Y} \square \mid \mathrm{N} \square$ & $\mathrm{Y} \square \mid \mathrm{N} \square$ & White $\square$ | Black $\square$ | Hispanic $\square$ | Other $\square$ & & \\
\hline 103 ABC Street & $\mathrm{Y} \square \mid \mathrm{N} \square$ & $\mathrm{Y} \square \mid \mathrm{N} \square$ & White $\square$ | Black $\square$ | Hispanic $\square$ | Other $\square$ & & \\
\hline 104 ABC Street & $\mathrm{Y} \square \mid \mathrm{N} \square$ & $\mathrm{Y} \square \mid \mathrm{N} \square$ & White $\square$ | Black $\square$ | Hispanic $\square$ | Other $\square$ & & \\
\hline 105 ABC Street & $\mathrm{Y} \square \mid \mathrm{N} \square$ & $\mathrm{Y} \square \mid \mathrm{N} \square$ & White $\square$ | Black $\square$ | Hispanic $\square$ | Other $\square$ & & \\
\hline $106 \mathrm{ABC}$ Street & $\mathrm{Y} \square \mid \mathrm{ND}$ & $\mathrm{Y} \square \mid \mathrm{N} \square$ & White $\square$ | Black $\square$ | Hispanic $\square$ | Other $\square$ & & \\
\hline 107 ABC Str eet & Y $\square \mid N \square$ & $\mathrm{Y} \square \mid \mathrm{N} \square$ & White $\square$ | Black $\square$ | Hispanic $\square$ | Other $\square$ & & \\
\hline 108 ABC Street & $\mathrm{Y} \square \mid \mathrm{N} \square$ & $\mathrm{Y} \square \mid \mathrm{N} \square$ & White $\square$ | Black $\square$ | Hispanic $\square$ | Other $\square$ & & \\
\hline 109 ABC Street & $\mathrm{Y} \square \mid \mathrm{N} \square$ & $\mathrm{Y} \square \mid \mathrm{N} \square$ & White $\square$ | Black $\square$ | Hispanic $\square$ | Other $\square$ & & \\
\hline 110 ABC Street & $\mathrm{Y} \square \mid \mathrm{N} \square$ & $\mathrm{Y} \square \mid \mathrm{N} \square$ & White $\square$ | Black $\square$ | Hispanic $\square$ | Other $\square$ & & \\
\hline $111 \mathrm{ABC}$ Street & $\mathrm{Y} \square \mid \mathrm{N} \square$ & $\mathrm{Y} \square \mid \mathrm{N} \square$ & White $\square$ | Black $\square$ | Hispanic $\square$ | Other $\square$ & & \\
\hline $112 \mathrm{ABC}$ Street & $\mathrm{Y} \square \mid \mathrm{N} \square$ & $\mathrm{Y} \square \mid \mathrm{N} \square$ & White $\square$ | Black $\square$ | Hispanic $\square$ | Other $\square$ & & \\
\hline 113 ABC Street & $\mathrm{Y} \square \mid \mathrm{N} \square$ & $\mathrm{Y} \square \mid \mathrm{N} \square$ & White $\square$ | Black $\square$ | Hispanic $\square$ | Other $\square$ & & \\
\hline
\end{tabular}

Note: Addresses have been falsified to protect subject identity. 
Appendix III: Holiday card

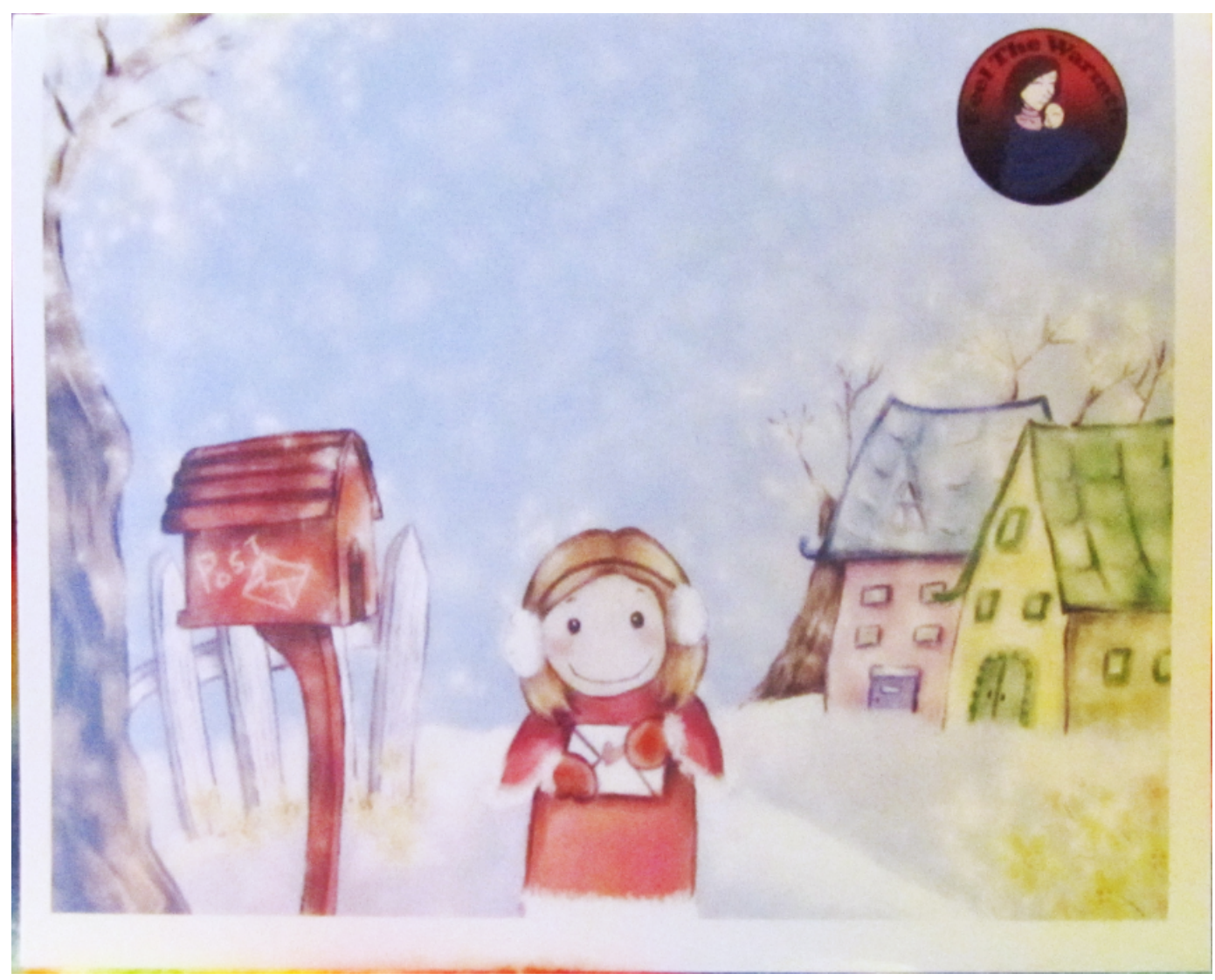




\section{Appendix IV: Additional Figures}

Figure A1: Histogram Distribution of Full Sample

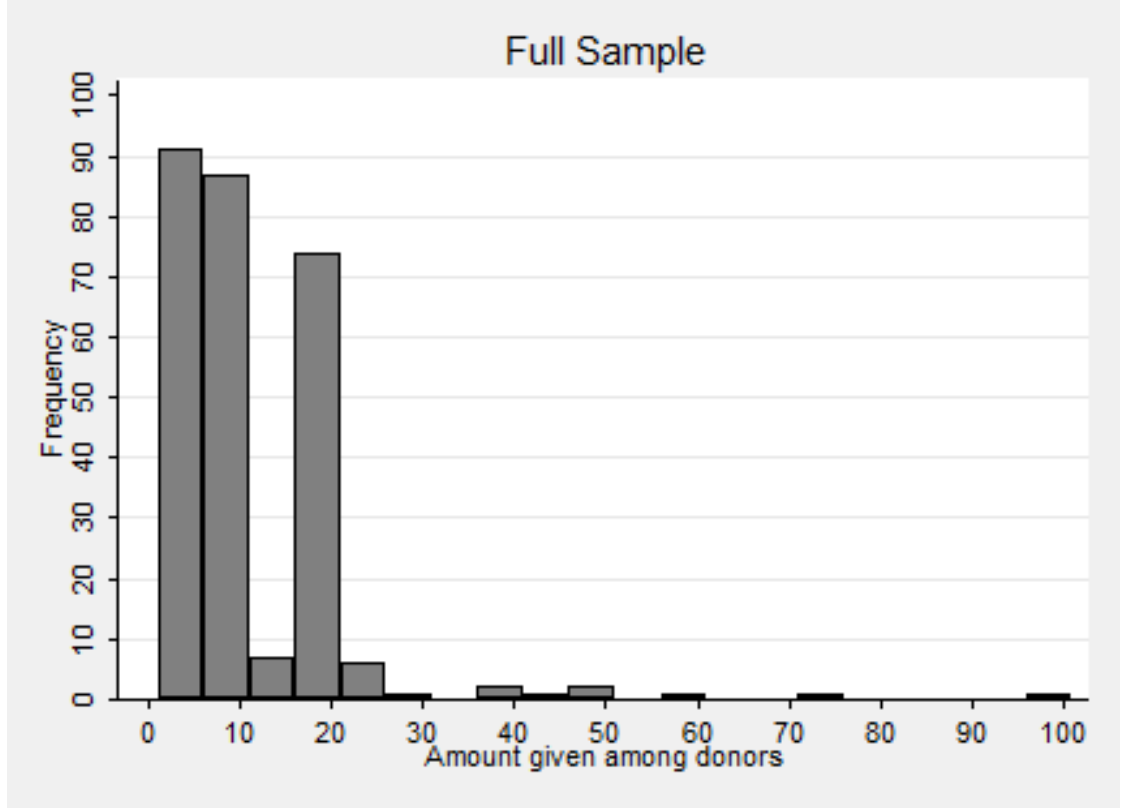

Figure A2: Histogram of all donations by treatment (includes \$0)

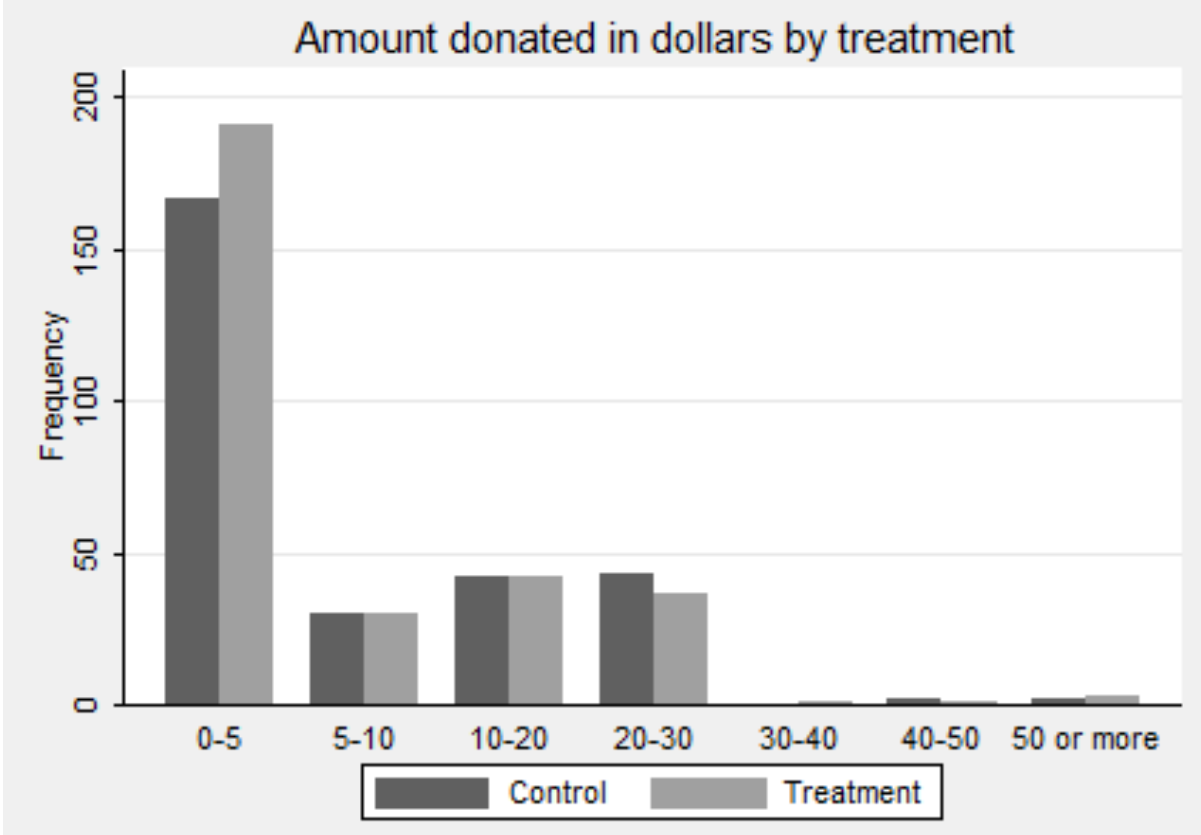

